\title{
EFEKTIVITAS DIKLAT KARYA TULIS ILMIAH TERHADAP KOMPETENSI MENULIS WIDYAISWARA
}

\author{
Nanan Nahriah \\ Badan Litbang dan Diklat Kementerian Agama \\ nanannahriah@gmail.com
}

https://doi.org/10.36052/andragogi.v8i1.132

Diterima: 22 April 2020 | Disetujui: 29 Juni 2020 | Dipublikasikan: 30 Juni 2020

\begin{abstract}
Abstrak
Tujuan penelitian ini untuk mendeskripsikan efektivitas diklat karya tulis ilmiah terhadap kompetensi menulis widyaiswara berkenaan dengan perumusan permasalahan penelitian, penyusunan kajian teori, perumusan metode penelitian, penyusunan hasil dan pembahasan, dan penyusunan simpulan dan saran. Penelitian ini adalah penelitian deskriptif kualitatif. Penelitian dilaksanakan di Pusdiklat Tenaga Teknis Pendidikan dan Keagamaan. Subjek penelitian adalah 10 orang Widyaiswara yang telah mengikuti diklat KTI bagi Widyaiswara. Teknik pengumpulan data adalah studi dokumentasi sedangkan teknik analisis data menggunakan analisis data kualitatif. Hasil penelitian menunjukkan bahwa Diklat KTI efektif dalam mengembangkan kompetensi Widyaiswara dalam menyusun artikel ilmiah hasil penelitian. Hasil penelitian mengungkap bahwa semua naskah sudah mencantumkan permasalahan penelitian baik di bagian pendahuluan, isi, dan penutup, walaupun ungkapan istilahnya tidak persis sama dengan pedoman penulisan namun esensinya relevan dengan permasalahan. Ada yang diungkapkan secara explisit dan ada yang secara implisit. Berdasarkan hasil penelitian, peneliti menyampaikan saran agar Pusdiklat tetap memprogramkan diklat KTI bagi Widyaiswara.
\end{abstract}

Kata kunci: efektivitas, pelatihan, kompetensi, dan menulis.

\begin{abstract}
[THE EFFECTIVENESS OF THE TRAINING OF SCIENTIFIC PAPERS ON WIDYAISWARA WRITING COMPETENCE] The purpose of this study is to describe the effectiveness of the training of scientific article on widyaiswara writing competence regarding the formulation of research problems, the formulation of theoretical studies, the formulation of research methods, the preparation of results and discussion, and the presentation of conclusions and suggestions. This research is a qualitative descriptive study. The research was carried out in the Education and Religious Technical Training Center. The research subjects were 10 widyaiswara who had participated in the training on scientific writing. Data collection techniques are documentation studies while data analysis techniques are using qualitative data analysis techniques. The results of the study showed that the training of scientific writing for widyaiswara was effective in developing the widyaiswara's competence in writing scientific papers. It revealed that all documents had included research problems in the introduction, content, and closing, although the terminology is not exactly the same as the writing guidelines but the essence is relevant to the problem. Some are explicitly disclosed and some are implicitly. Based on the results of the study, the researcher proposed a suggestion that the Pusdiklat continue to program scientific papers training for Widyaiswara.
\end{abstract}

Keywords: effectiveness, training, competence, and writing.

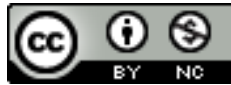

This work is licensed under a Creative Commons Attribution-NonCommercial 4.0 International License 


\section{PENDAHULUAN}

K

arya Tulis IImiah (KTI) merupakan aspek pengembangan profesi Widyaiswara dalam menyampaikan gagasan, ide, dan pikiran terkait kediklatan baik berbentuk hasil penelitian atau kajian yang mengacu pada Peraturan Kepala Lembaga Administrasi Negara (PerKaLAN) Nomor 9 Tahun 2008 tentang Pedoman Penyusunan KTI Bagi Widyaiswara.

KTI menjadi salah satu sub unsur utama dalam penilaian angka kredit Widyaiswara dan menjadi syarat yang harus dipenuhi jumlah minimal angka kreditnya pada setiap jenjang kepangkatan. Widyaiswara tidak dapat naik pangkat atau jabatannya bila sub unsur KTI ini tidak dapat dipenuhi meskipun unsur lainnya telah terpenuhi. Dengan demikian, kemampuan menulis bagi Widyaiswara perlu terus dikembangkan baik kualitas maupun kuantitas.

Berdasarkan peraturan yang telah ditetapkan mengenai bobot yang dipersyaratkan untuk pemenuhan angka kredit dari unsur pengembangan profesi merupakan suatu tantangan bagi Widyaiswara untuk lebih intens dalam menyusun KTI dengan mengikuti aturan penulisan yang sesuai kriteria penilaian Tim Penilai KTI Widyaiswara dan dengan menggunakan kaidah APIKO (Asli, Perlu, Ilmiah, Konsisten, Objektif) serta sistematika penulisan.

Untuk mengetahui tata cara serta sistematika penulisan secara detail dan penyusunan artikel ilmiah hasil penelitian layak dimuat dalam jurnal, perlu diadakan pembinaan khusus melalui Diklat Karya Tulis Ilmiah, maka Widyaiswara seyogyanya memiliki bekal dalam penyusunan artikel ilmiah hasil penelitian dan mengikuti pedoman penulisan yang berlaku.

Namun berdasarkan pada data statistik hasil penilain Tim Penilai KTI Widyaiswara, fakta di lapangan ditemukan beberapa penulisan KTI Widyaiswara kurang memenuhi persyaratan sehingga pemenuhan angka kredit dari aspek pengembangan profesi masih sangat kurang. Kekurangan tersebut antara lain; tidak semua KTI Widyaiswara menguraikan tujuan penulisan KTI, kajian pustaka/teori/rujukan yang kurang lengkap dan tidak sesuai dengan permasalah atau kurang mutakhir, tidak dijelaskan metode penelitian, tidak terdapat identifikasi masalah, tidak adanya rumusan masalah, pembahasan, uraian, atau temuan tidak sesuai dengan rumusan, masalah tidak sesuai dengan temuan, permasalahan tidak fokus serta permasalah-permasalahan lain yang sangat signifikan pada pemenuhan kriteria penulisan KTI.

Untuk mengetahui bagaimana sesungguhnya penyusunan KTI widyaiwara yang sudah dibuat dan diajukan untuk angka kredit, maka dilakukan penelitian mengenai efektivitas diklat KTI terhadap kompetensi menulis Widyaiswara.

Berdasarkan permasalahan tersebut, maka perumusan penelitian ini adalah bagaimana efektivitas diklat KTI terhadap kemamuan menulis Widyaiswara terutama dalam beberapa hal, yakni dalam perumusan permasalahan penelitian, penyusunan kajian teori, perumusan metode penelitian, penyusunan hasil dan pembahasan, dan penyusunan simpulan dan saran/rekomendasi.

Hasil penelitian ini diharapkan dapat menambah wawasan, pendalaman materi penulisan Karya Tulis Ilmiah, sarana dalam pengembangan profesi dan bahan acuan/penelitian pendahuluan untuk penelitian selanjutnya. Bagi Widyaiswara dapat memberikan alternatif strategi menulis Karya Tulis Ilmiah dan meningkatkan intensitas penulisan Karya Tulis Ilmiah. Bagi lembaga bermanfaat sebagai informasi dalam kelangsungan pelaksanaan diklat Karya Tulis IImiah bagi Widyaiswara pada waktu berikutnya.

Berdasarkan penelusuran yang dilakukan, terdapat beberapa artikel dalam Jurnal Ilmiah tentang penulisan $\mathrm{KTI}$ ini, penelitian terdahulu yang sesuai fokus penelitian ini adalah jurnal yang disusun oleh Ryan Arthur menulis tentang “Evaluasi Program Diklat KTI untuk Widyaiswara Pusbangtendik Kemdikbud", penelitian ini fokus pada mengevaluasi pelaksanaan program diklat KTI. Jurnal yang berjudul "Motivasi Widyaiswara dalam Menulis KTI (Studi Kasus pada Peserta Diklat Karya Tulis Ilmiah di LAN" yang ditulis oleh Meyke 
Alie, penelitian ini menyoroti masalah motivasi Widyaiswara. Namun untuk masalah yang dipilih pada penelitian ini belum ada yang membahasnya di kalangan widyaiswara dan masalah ini merupakan masalah yang sangat penting untuk diteliti karena menyangkut kemampuan widyaiswara dalam menulis KTI yang selanjutnya akan berimbas pada kelancaran pengajuan angka kredit Widyaiswara.

Adapun kajian teori dalam penelitian ini mencakup efektivitas, pelatihan, kompetensi, dan menulis serta teori-teori yang relevan dengan permasalahan yang diungkap dalam penelitian ini.

Dalam Makmur (2011:6) disebutkan bahwa kegiatan yang dilakukan itu efektif apabila di dalam proses pelaksanaannya terdapat kesesuaian antara harapan yang diinginkan dengan hasil yang dicapai.

Menurut Bangun (2008:4-5) Efektivitas maksudnya melakukan suatu kegiatan sesuai dengan yang diharapkan dan terpenuhinya target yang ingin dicapai.

Selanjutnya menurut Hermansyah \& Tamim (2002: 35), efektivitas diklat dapat terlihat antara lain dari terlaksananya seluruh program diklat sesuai dengan jadwal waktu yang telah ditetapkan, rapinya penyelenggaraan seluruh kegiatan diklat berkat disiplin kerja, dedikasi dan kemampuan para penyelenggara, efisiensi dalam penggunaan sarana dan prasarana yang tersedia dan tercapainya sasaran yang telah ditetapkan bagi program diklat.

Berdasarkan pernyataan di atas dapat disimpulkan bahwa salah satu indikator efektifnya pelaksanaan pendidikan dan pelatihan adalah tercapainya sasaran yang telah ditetapkan dan sesuai dengan target bagi program diklat. Dengan demikian diklat KTI bagi Widyaiswara dapat dikatakan efektif apabila Widyaiswara yang menjadi peserta diklat tersebut dapat menulis KTI dengan benar.

Mengenai pelatihan, Simamora (2006:273) berpendapat bahwa "pelatihan merupakan proses pembelajaran yang melibatkan perolehan keahlian, konsep, peraturan, atau sikap untuk meningkatkan kinerja". Sedangkan Sembiring (2012:55) berpendapat bahwa, "pelatihan merupakan salah satu cara untuk dapat mengembangkan kemampuan dan keahlian karyawan sehingga dapat menyesuaikan diri dan memahami teknologi yang senantiasa berkembang dari waktu ke waktu." Berdasarkan definisi tersebut dapat dikatakan bahwa pelatihan adalah sebuah alat perantara untuk melatih peserta pelatihan memperoleh ilmu pengetahuan dan suatu keahlian yang dapat digunakan oleh peserta pelatihan dalam bidangnya serta melatih peserta pelatihan agar mampu melakukan penelitian dengan memanfaatkan teknologi.

Pendidikan dan pelatihan sebagai bagian integral dari kebijakan personil dalam rangka pembinaan Widyaiswara juga merupakan alat untuk menyesuaikan antara tanggung jawab dan pekerjaan dengan kemampuan, keterampilan, kecakapan, dan keahlian dari Widyaiswara. Kebijaksanaan Instansi menyarankan agar setiap Widyaiswara diberi kesempatan untuk melanjutkan pendidikan dan pengembangan, sehingga dapat meningkatkan pengetahuan serta keterampilan yang pada akhirnya mampu meningkatkan kompetensi Widyaiswara khususnya dalam menulis artikel ilmiah hasil penelitian.

Kompetensi adalah kata yang diadaptasi dari bahasa Inggris yaitu "competence" yang artinya kemampuan. Dalam KBBI tercantum bahwa kompetensi adalah kemampuan atau keahlian. Pengertian kompetensi menurut Kepala Badan Kepegawaian Negeri Nomor 46A Tahun 2003 adalah kemampuan dan karakteristik yang dimiliki oleh seorang Pegawai Negeri Sipil berupa pengetahuan, keterampilan, dan sikap perilaku yang diperlukan dalam pelaksanaan tugas jabatannya, sehingga Pegawai Negeri Sipil tersebut dapat melaksanakan tugasnya secara profesional, efektif, dan efisien. Jadi kompetensi adalah kemampuan dalam melaksanakan tugas yang dilandasi oleh sikap, pengetahuan, dan keterampilan yang terdapat pada diri seorang pegawai, begitupun dengan kemampuan Widyaiswara dalam melaksanakan tugas dan fungsinya.

Mengenai menulis, Suparno \& Yunus (2008:13) menguraikan bahwa menulis merupakan suatu kegiatan penyampaian pesan 
atau komunikasi dengan menggunakan bahasa tulis sebagai alat atau medianya. Melengkapi pendapat di atas, Saddhono \& Slamet (2012:103) menyatakan bahwa keterampilan menulis mencakup berbagai kemampuan misalnya kemampuan menggunakan unsurunsur bahasa secara tepat, kemampuan mengorganisasikan wacana dalam bentuk karangan, kemampuan menggunakan bahasa yang tepat, pilihan kata serta lainnya. Jadi dapat dikatakan bahwa keterampilan menulis merupakan kegiatan memberikan informasi kepada orang lain baik pengetahuan maupun fenomena berdasarkan gagasan atau ide yang dituangkan dalam tulisan. Begitupun dengan widyaiswara, kemampuan Widyaiswara dalam menulis pun dilandasi oleh kemampuan sikap, pengetahuan, dan keterampilan yang bertujuan memberikan informasi mengenai gagasan atau ide yang berhubungan dengan tugas dan fungsi Widyaiswara.

Selanjutnya teori yang mendukung bagian isi dari perumusan permasalahan penelitian diantaranya;

1) Penyusunan Pendahuluan yang meliputi latar belakang masalah, identifikasi masalah, tujuan, dan manfaat penulisan.

2) Kajian teori/tinjauan pustaka. Dalam pedoman KTI Widyaiswara disebutkan bahwa isi dari kajian teori adalah kajian kepustakaan, teori pendukung yang mutakhir dan relevan dengan obyek, dan definisi operasional variabel dan indikator yang digunakan.

Dalam Modul Metode Penelitian II (Sobandi: 2016) disebutkan bahwa tinjauan pustaka meliputi kajian teori dan kebijakan, kerangka berfikir, operasionalisasi variabel (jika pendelatan kuantitatif dan metode eksplanasi) atau konsep kunci (jika pendekatan kualitatif dan metode deskripsi atau eksplorasi), dan hipotesis (jika pendekatan kuantitatif dan metode eksplanasi) atau pertanyaan penelitian (jika pendekatan kualitatif dan metode deskripsi atau eksplorasi).

Sedangkan menurut Suhardjono (2015:145), kajian teori/tinjauan pustaka; setidaknya berisi variabel masalah yang dijadikan fokus penelitian, variabel tindakan yang akan dilakukan untuk mengatasi masalah penelitian, dan bagaimana kerangka fikir bahwa dengan tindakan itu mampu mengatasi masalah yang dialami.

Perumusan metode Penelitian berkaitan dengan teknik dan prosedur yang digunakan dalam penelitian. Metode penelitian yang dikutif dari Modul (Sobandi, 2016:12) apabila ditinjau dari tujuannya terdiri dari metode deskripsi, eksplorasi, dan eksplanasi. Metode penelitian deskripsi menggambarkan suatu situasi fenomena secara detail dan lebih menekankan pada menjawab pertanyaan "how" (bagaimana) dan "who" (siapa). Metode Eksplorasi adalah penelitian eksplorasi merupakan penelitian yang dimaksudkan untuk menjajagi suatu fenomena baru yang mungkin belum ada penelitian yang dilakukan sebelumnya. Metode Eksplanasi adalah penelitian yang memfokuskan pada pertanyaan "why" (kenapa).

Dalam pedoman KTI Widyaiswara disebutkan bahwa penyusunan hasil dan pembahasan penelitian meliputi pengungkapan permasalahan, pembahasan atas fakta atau peristiwa di lapangan, uraian dan analisis tinjauan/ulasan ilmiah, dan pembahasan/analisis atas fakta hasil penelitian/pengkajian dan dikaitkan dengan teori. Dalam modul Metode Penelitian (Sobandi: 2016) disebutkan bahwa dalam pembahasan dan hasil penelitian dapat dibagi dalam beberapa sub bagian sesuai dengan keperluan. Pada bagian ini juga disajikan pengujian hipotesis dan hasilnya (jika penelitian eksplanasi kuantitatif). Dan menurut Suhardjono bahwa hasil dan pembahasan merupakan hasil karya dari seluruh pikiran, pengamatan tanpa didasarkan pada pendapat peneliti lain.

Dalam pedoman KTI Widyaiswara disebutkan bahwa dalam bagian penutup memuat kesimpulan dan saran/rekomendasi. Menurut Sobandi (2016) kesimpulan dan rekomendasi berisi kesimpulan dari penelitian yang dilakukan, dengan mengungkapkan kelebihan dan kekurangan dari metode yang digunakan ataupun saran kebijakan kepada pihak-pihak yang terkait dengan substansi penelitian tersebut Selain itu, diungkapkan pula rekomendasi yang berisi kemungkinan penelitian lebih lanjut, dan tindakan yang 
harus dilakukan oleh pihak-pihak yang terkait dengan substansi penelitian.

Menurut Suhardjono (2015) kesimpulan sebaiknya memenuhi ciri-ciri;

a) singkat, jelas, dan padat, merupakan intisari dari suatu analisis/pembahasan dari suatu masalah.

b) Harus konsisten antara pembahasan dan kesimpulan.

c) Harus disusun berdasarkan rumusan masalah dan tujuan penelitian.

Sedangkan saran yang perlu diperhatikan yaitu:

a) Saran harus berpijak pada kesimpulan hasil penelitian yang dilakukan;

b) Arah dari saran harus jelas dan operasional atau bersifat konkrit dan dapat dilaksanakan.

\section{METODE PENELITIAN}

Penelitian ini berlokasi dimana tempat peneliti bekerja yaitu pada Pusdiklat Tenaga Teknis Pendidikan dan Keagamaan RI yang terletak di Jl. Ir, H, Juanda No. 37 Ciputat yang dilakukan pada Februari dan Maret 2019.

Penelitian ini menggunakan metode deskriptif dengan pendekatan kualitatif. Menurut Suharsaputra (Sobandi: 2016) dalam penelitian deskripsi dimulai dengan subjek yang terdefinisikan dengan baik kemudian mendeskripsikannya dengan akurat dan dalam mengumpulkan data umumnya menggunakan teknik wawancara, observasi, dan analisis konten. Selanjutnya dijelaskan bahwa dalam penelitian kualitatif wawancara umumnya dimaksudkan untuk lebih mendalami suatu kejadian dan atau kegiatan subjek penelitian (wawancara mendalam/in-depth interview).

Metode desktiptif yang dilakukan dalam penelitian ini adalah untuk menggambarkan fenomena mengenai alasan dasar atas penolakan angka kredit Widyaiswara berdasarkan hasil penilaian Tim Penilai sehingga dapat diketahui bagaimana cara Widyaiswara dalam penyusunan artikel hasil penelitian.

Sedangkan wawancara pada penelitian ini dilakukan untuk lebih menyamakan persepsi responden dengan hasil artikel yang diobservasi dan memperkuat data yang diambil secara kuesioner. Sumber data dan informasi dalam penelitian deskriptif dapat berupa orang (sebagai responden/informan), benda, keadaan, dan lain-lain, seperti buku-buku teks, indeks, jurnal penelitian (sebagai sumber studi kepustakaan), menurut Suharsaputra (Sobandi: 2016).

Dalam penelitian ini, Objek/sumber data dilakukan pada artikel ilmiah hasil penelitian Widyaiswara Pusdiklat Teknis Pendidikan dan Keagamaan yang telah dimuat dalam jurnal. Populasi dalam penelitian ini adalah seluruh Widyaiswara Pusdiklat Teknis Pendidikan dan Keagamaan yang berjumlah 24 Widyaiswara. Dari 24 populasi tersebut mempunyai kesempatan yang sama menjadi sampel. Ukuran sampel ditentukan atas dasar teori kejenuhan (titik dalam pengumpulan data saat data baru tidak lagi membawa wawasan tambahan untuk pertanyaan penelitian).

Penelitian ini menggunakan data primer yang bersumber dari penulis jurnal kemudian data sekunder meliputi dokumen, arsip, catatan, dan laporan resmi.

Instrumen yang digunakan dalam pengumpulan data adalah lembar pengamatan, pedoman wawancara, dan catatan lapangan (field-notes). Untuk observasi menggunakan lembar pengamatan, Untuk wawancara menggunakan pedoman wawancara, Untuk studi dokumentasi menggunakan dokumen atau catatan lapangan (field-notes).

Teknik pengumpulan data dilakukan melalui pedoman wawancara, observasi, dan studi dokumentasi. Melakukan wawancara dengan penulis artikel. Peneliti melakukan tanya jawab dengan responden menggunakan alat yang dinamakan panduan wawancara (interview guide) untuk memperoleh data tentang pemahaman Widyaiswara dalam Penyusunan Artikel Ilmiah Hasil Penelitian yang nantinya akan disesuaikan dengan artikel yang diteliti yang sudah terbit di Jurnal. Melakukan observasi atau pengamatan terhadap artikel.

Penelitian dilakukan terhadap 10 (sepuluh) artikel Widyaiswara yang telah terbit dalam satu Jurnal dengan menggunakan model analisis interaktif dari Miles dan Huberman (Sugiono, 2009:337) yang terdiri dari pengumpulan data, reduksi data, penyajian data, dan yang terakhir yaitu penarikan 
kesimpulan. Sedangkan studi dokumentasi dilakukan dengan cara melakukan breakdown pada hasil penilaian Tim penilai terhadap KTI Widyaiswara yang sudah dipublish.

Tehnik pengolahan data yang digunakan merujuk pada Miles \& Huberman dengan alur reduksi data (proses pengolahan data yang ditemukan lalu dikumpulkan dan dipilih-pilih kemudian data disederhanakan dan dirangkum yang sesuai dengan fokus masalah dalam peneltian), sajian data (proses menyajikan data supaya lebih sistematis, data yang sudah direduksi diperiksa kembali, sehingga dapat tergambar data secara keseluruhan kemudian dilakukan penelusuran data kembali apabila masih dibutuhkan untuk lebih mendalami masalahnya), dan penarikan kesimpulan yang disertai verifikasi serta interpretasi data.

Data yang sudah diperoleh, diolah dengan menggunakan pendekatan kualitatif. Proses interpretasi data dilakukan secara triangulasi yakni interpretasi dilakukan setelah peneliti melakukan pemaduan antar berbagai data yang terkumpul dari hasil observasi, hasil wawancaram dan hasil studi dokumentasi.

Data hasil penelitian digunakan untuk mengetahui efektivitas Diklat KTI Terhadap Kemampuan Widyaiswara dalam Penyusunan Artikel Ilmiah Hasil Penelitian (Studi kasus pada Pusdiklat Tenaga Teknis Pendidikan dan Keagamaan RI). Pengolahan data yang digunakan merujuk pada Miles \& Huberman dengan alur reduksi data, sajian data, dan penarikan kesimpulan yang disertai verifikasi serta interpretasi data.

Data yang sudah diperoleh, diolah dengan menggunakan pendekatan kualitatif. Proses interpretasi data dilakukan secara triangulasi yakni interpretasi dilakukan setelah peneliti melakukan pemaduan antar berbagai data yang terkumpul dari hasil observasi, hasil wawancara dan hasil studi dokumentasi.

Data hasil penelitian digunakan untuk mengetahui efektivitas Diklat KTI Terhadap Kemampuan Widyaiswara dalam Penyusunan Artikel Ilmiah Hasil Penelitian (Studi kasus pada Pusdiklat Tenaga Teknis Pendidikan dan Keagamaan RI).

\section{TEMUAN DAN PEMBAHASAN}

\section{Temuan}

Berdasarkan rumusan masalah penelitian, maka pada bagian ini akan dibahas tentang efektivitas diklat bagi Widyaiswara dalam perumusan permasalahan penelitian, perumusan kerangka teori, perumusan metode penelitian, penyusunan hasil dan pembahasan, dan penyusunan kesimpulan dan saran.

Temuan penelitian dibahas berdasarkan studi dokumentasi terhadap 10 naskah KTI Widyaiswara yang sudah dipublish di Jurnal Andragogi Pusdiklat Teknis tahun 2017. Data hasil analisis dapat dilihat pada tabel di bawah ini:

Tabel 1. Data Hasil Studi Dokumentasi

\begin{tabular}{|c|c|c|c|c|c|c|}
\hline \multirow{3}{*}{ No. } & \multirow{3}{*}{ Penulis } & \multicolumn{5}{|c|}{ Aspek yang Diteliti dan Temuan } \\
\hline & & 1 & 2 & 3 & 4 & 5 \\
\hline & & $\begin{array}{l}\text { Perumusan } \\
\text { Masalah }\end{array}$ & Kajian Teori & Metode Penelitian & $\begin{array}{l}\text { Temuan dan } \\
\text { Pembahasan }\end{array}$ & $\begin{array}{c}\text { Simpulan dan } \\
\text { Saran }\end{array}$ \\
\hline 1 & 01.1 & $\begin{array}{l}\text { Tidak ada kata } \\
\text { "rumusan } \\
\text { masalah" yang } \\
\text { ada tujuan. }\end{array}$ & $\begin{array}{l}\text { Tidak } \\
\text { lengkap }\end{array}$ & $\begin{array}{l}\text { Sudah rinci dan } \\
\text { jelas }\end{array}$ & $\begin{array}{l}\text { Sesuai dengan } \\
\text { tujuan }\end{array}$ & $\begin{array}{l}\text { Sesuai dengan } \\
\text { tujuan }\end{array}$ \\
\hline 2 & 01.2 & $\begin{array}{l}\text { Tidak ada kata } \\
\text { "rumusan } \\
\text { masalah" yang } \\
\text { ada tujuan }\end{array}$ & $\begin{array}{l}\text { Tidak } \\
\text { lengkap }\end{array}$ & Tidak lengkap & $\begin{array}{l}\text { Sesuai dengan } \\
\text { tujuan penelitian }\end{array}$ & $\begin{array}{l}\text { Sesuai dengan } \\
\text { tujuan penelitian }\end{array}$ \\
\hline 3 & 01.3 & $\begin{array}{l}\text { Ada rumusan } \\
\text { masalah dan } \\
\text { tujuan }\end{array}$ & $\begin{array}{l}\text { Tidak } \\
\text { lengkap }\end{array}$ & $\begin{array}{l}\text { Sudah rinci dan } \\
\text { jelas }\end{array}$ & $\begin{array}{l}\text { Sesuai dengan } \\
\text { rumusan } \\
\text { masalah }\end{array}$ & $\begin{array}{l}\text { Sesuai dengan } \\
\text { rumusan masalah }\end{array}$ \\
\hline 4 & 01.4 & Tidak ada kata & Tidak ada & Diuraikan secara & Sesuai dengan & Sesuai dengan \\
\hline
\end{tabular}




\begin{tabular}{|c|c|c|c|c|c|c|}
\hline & & $\begin{array}{l}\text { "rumusan } \\
\text { masalah" yang } \\
\text { ada "fokus" dan } \\
\text { tujuan } \\
\text { penelitian }\end{array}$ & $\begin{array}{l}\text { kajian } \\
\text { teorinya } \\
\text { sama sekali }\end{array}$ & $\begin{array}{l}\text { garis besar saja. } \\
\text { Ada kajian teori. }\end{array}$ & fokus penelitian & fokus penelitian \\
\hline 5 & 01.5 & $\begin{array}{l}\text { Ada rumusan } \\
\text { masalah dan } \\
\text { tujuan }\end{array}$ & $\begin{array}{l}\text { Tidak } \\
\text { lengkap }\end{array}$ & $\begin{array}{l}\text { Sudah rinci dan } \\
\text { jelas }\end{array}$ & $\begin{array}{l}\text { Sesuai dengan } \\
\text { rumusan } \\
\text { masalah }\end{array}$ & $\begin{array}{l}\text { Sesuai dengan } \\
\text { rumusan masalah }\end{array}$ \\
\hline 6 & 01.6 & $\begin{array}{l}\text { Ada rumusan } \\
\text { masalah dan } \\
\text { tujuan }\end{array}$ & $\begin{array}{l}\text { Sesuai } \\
\text { dengan } \\
\text { rumusan } \\
\text { masalah }\end{array}$ & $\begin{array}{l}\text { Tidak ada } \\
\text { metode } \\
\text { penelitian }\end{array}$ & $\begin{array}{l}\text { Hasil hanya } \\
\text { pendapat para } \\
\text { pakar. } \\
\text { Pembahasan } \\
\text { sesuai dengan } \\
\text { rumusan } \\
\text { masalah }\end{array}$ & $\begin{array}{l}\text { Simpulan } \\
\text { pengulangan dari } \\
\text { uraian di atas. } \\
\text { Saran sesuai } \\
\text { dengan rumusan } \\
\text { masalah }\end{array}$ \\
\hline 7 & 01.7 & $\begin{array}{l}\text { Ada rumusan } \\
\text { masalah dan } \\
\text { tujuan }\end{array}$ & $\begin{array}{l}\text { Tidak } \\
\text { lengkap }\end{array}$ & $\begin{array}{l}\text { Sudah rinci dan } \\
\text { jelas }\end{array}$ & $\begin{array}{l}\text { Sesuai dengan } \\
\text { rumusan } \\
\text { masalah }\end{array}$ & $\begin{array}{l}\text { Sesuai dengan } \\
\text { rumusan masalah }\end{array}$ \\
\hline 8 & 02.5 & $\begin{array}{l}\text { Ada rumusan } \\
\text { masalah dan } \\
\text { tujuan }\end{array}$ & $\begin{array}{l}\text { Sesuai } \\
\text { dengan } \\
\text { rumusan } \\
\text { masalah }\end{array}$ & $\begin{array}{l}\text { Uraiannya } \\
\text { kurang jelas }\end{array}$ & $\begin{array}{l}\text { Sesuai dengan } \\
\text { rumusan } \\
\text { masalah }\end{array}$ & $\begin{array}{l}\text { Pengulangan data } \\
\text { hasil analisis. } \\
\text { Saran sesuai } \\
\text { dengan rumusan } \\
\text { masalah. }\end{array}$ \\
\hline 9 & 02.6 & $\begin{array}{l}\text { Ada rumusan } \\
\text { masalah dan } \\
\text { tujuan }\end{array}$ & $\begin{array}{l}\text { Sesuai } \\
\text { dengan } \\
\text { rumusan } \\
\text { masalah }\end{array}$ & $\begin{array}{l}\text { Sudah rinci dan } \\
\text { jelas }\end{array}$ & $\begin{array}{l}\text { Sesuai dengan } \\
\text { rumusan } \\
\text { masalah }\end{array}$ & $\begin{array}{l}\text { Sesuai dengan } \\
\text { rumusan masalah }\end{array}$ \\
\hline 10 & 02.7 & $\begin{array}{l}\text { Ada rumusan } \\
\text { masalah dan } \\
\text { tujuan }\end{array}$ & $\begin{array}{l}\text { Tidak } \\
\text { lengkap }\end{array}$ & $\begin{array}{l}\text { Tidak ada proses } \\
\text { pengolahan data } \\
\text { dan analisa data }\end{array}$ & $\begin{array}{l}\text { Tidak sesuai } \\
\text { dengan rumusan } \\
\text { masalah }\end{array}$ & $\begin{array}{l}\text { Tidak sesuai } \\
\text { dengan rumusan } \\
\text { masalah }\end{array}$ \\
\hline
\end{tabular}

Dari Tabel 1 di atas ditemukan data bahwa terdapat dua macam temuan naskah yang berkenaan dengan rumusan masalah. Ada naskah yang mencantumkan rumusan masalah secara eksplisit dan ada yang secara implisist. Sebagian besar naskah sudah mencantumkan perumusan masalah penelitian secara explisit dan ada yang menggunakan kedua-duanya yaitu rumusan masalah dan tujuan penelitian yaitu data dengan kode 01.3.N, 01.5.E, 01.6.A, 01.7.A, 02.5.Y, 02.6.D, dan 02.7.Y dan ada tiga naskah yang mencantumkan rumusan masalah secara implisit. Dalam naskah tersebut dinyatakan "Tujuan penelitian ini adalah...." yaitu data dengan kode 01.1.F dan 01.2.D, sedangkan naskah dengan kode 02.4.B memaparkan rumusan masalah penelitian secara implisit. Dalam naskah tersebut dinyatakan" Fokus penelitian ini adalah....".

Berkenaan dengan kerangka teori, berdasarkan data dokumentasi terungkap bahwa semua naskah sudah merumuskan kerangka teori dengan tepat. Teori dikembangkan berdasarkan variabel masalah yang diteliti namun ada enam naskah yang belum lengkap kerangka teorinya yaitu dengan kode 01.1.F, 01.2.D, 01.3.N, 01.5.E, 01.7.A, dan 02.7.Y. Kemudian ada tiga naskah naskah yang dianalisis sudah menggunakan kerangka teori yang tepat dengan kode 01.6.A, 02.5.Y, dan 02.6.D. dan ada satu naskah yang tidak mencantumkan kerangka teori yaitu dengan kode 01.4.B.

Dalam metode penelitian, berdasarkan hasil analisis data, 6 dari 10

naskah yang dianalisis sudah mencantumkan secara tegas metode penelitian yang dipilih, baik jenis maupun pendekatannya. Data dengan kode 01.1.F menggunakan metode penelitian content analysis, data dengan kode 01.3.N dan 01.7.A, menggunakan metode penelitian survei, data dengan kode 02.5.Y menggunakan bentuk eksperimen semu (quasi 
experiment). Data dengan kode 01.5.E menggunakan pendekatan kualitatif dengan studi kasus. Data dengan kode 02.7.Y menggunakan metode penelitian evaluation methods. Sedangkan data dengan kode 01.2.D, 01.4.B, dan 02.6.D tidak menyebutkan secara tegas metode penelitian. bahkan data dengan 01.6.A tidak mencantumkan metode penelitian sama sekali, kemudian data dengan kode 01.4.B mencantumkan kerangka teori di bagian metode penelitian.

Pada bagian hasil penelitian dan pembahasan, sebagian besar naskah yang dianalisis, sudah memaparkan hasil penelitian berdasarkan data yang telah dianalisis. Pada bagian pembahasan disajikan pembahasan berkenaan hasil penelitian. Namun terdapat satu naskah dengan kode 01.6.A yang diuraikan dalam hasil penelitian adalah pendapat para pakar tentang masalah yang diteliti dan satu naskah dengan kode 02.7.Y hasil dan pembahasannya tidak sesuai dengan rumusan masalah.

Demikian juga pada bagian penutup yaitu simpulan dan saran/rekomendasi. Simpulan merujuk ke hasil penelitian sedangkan saran merujuk ke kesimpulan. Dari hasil analisis ditemukan bahwa sebagian besar naskah sudah memuat simpulan dan saran. Namun ada dua naskah yang simpulannya berupa pengulangan uraian sebelumnya yaitu data dengan kode 01.6.A dan 01.5.Y. Kemudian data dengan kode 02.7.Y simpulan dan sarannya tidak sesuai dengan rumusan masalah.

Teknik selanjutnya yang digunakan dalam pengumpulan data sebagai data pendukung dilakukan melalui wawancara dengan penulis artikel.

Berdasarkan hasil wawancara dengan penulis artikel yaitu Widyaiswara Pusdiklat Tenaga Teknis Pendidikan dan Keagamaan ditemukan bahwa penulis sebagian besar sudah memahami kelima aspek yang diungkapkan dalam penelitian ini, seperti tabel di bawah ini:

Table 2. Data Hasil Wawancara I

\begin{tabular}{|c|c|c|}
\hline No. & Pertanyaan & Jawaban \\
\hline 1 & $\begin{array}{l}\text { Bagaimana pendapat Anda mengenai } \\
\text { perumusan permasalahan penelitian } \\
\text { dalam penulisan laporan hasil penelitian? }\end{array}$ & $\begin{array}{l}\text { - Perumusan permasalahan harus ada dalam setiap jenis } \\
\text { penilitian dan rumusan masalah harus dengan kalimat } \\
\text { tanya. } \\
\text { - Rumusan masalah bisa diambil dari judul tinggal ditambah } \\
\text { kata tanya didepannya, misalnya apa, bagaimana, dan } \\
\text { seterusnya. }\end{array}$ \\
\hline 2 & $\begin{array}{l}\text { Bagaimana pendapat Anda mengenai } \\
\text { kerangka teori dalam penulisan laporan } \\
\text { hasil penelitian? }\end{array}$ & $\begin{array}{l}\text { - Kerangka teori dalam penulisan laporan penelitian sangat } \\
\text { perlu karena merupakan salah satu konsep dasar } \\
\text { penelitian sosial, untuk menjelaskan hubungan sistematis } \\
\text { suatu fenomena dengan cara menspesifikasikan variabel } \\
\text { yang saling berhubungan. } \\
\text { - Kerangka teori juga membantu memahami sebuah } \\
\text { fenomena. } \\
\text { - Kerangka teori itu berisi konsep/teori yang mau ditulis, } \\
\text { judul apa? Nah judul itu dibahas berdasarkan teori yang } \\
\text { sudah atau para ahli lalu menyimpulkan dari teori itu, } \\
\text { atau boleh juga sependapat dengan teori A misalnya tapi } \\
\text { harus ada alasannya. Yang sudah ada/pendapat para ahli } \\
\text { kebanyakan penulis tidak menyimpulkan atau tidak } \\
\text { berpendapat justru disitu karya ilmiah atau penulis } \\
\text { menganalisis. }\end{array}$ \\
\hline 3 & $\begin{array}{l}\text { Bagaimana pendapat Anda mengenai } \\
\text { metode penelitian dalam penulisan } \\
\text { laporan hasil penelitian? }\end{array}$ & $\begin{array}{l}\text { - Metode penelitian untuk mengukur sampai seberapa jauh } \\
\text { hasil penelitian dapat dipertanggungjawabkan } \\
\text { kebenarannya. } \\
\text { - Metode penelitian harus sesuai dengan rumusan masalah, } \\
\text { subjek penelitian, dan data yang akan diperoleh sebagai } \\
\text { hasil penelitian. } \\
\text { - Kalau metode tergantung kamu menggunakan apa, }\end{array}$ \\
\hline
\end{tabular}


Metode kuantatif atau Metode kualitatif.

4 Bagaimana pendapat Anda mengenai penyusunan hasil pembahasan dalam penulisan?

5 Bagaimana pendapat Anda mengenai penyusunan kesimpulan dan saran dalam penulisan laporan hasil penelitian?
Pembahasan juga harus mengacu pada rumusan masalah, temuan yang didapatkan dibandingkan dengan teori yang mendukung atau yang bertolak belakang dari hasil penelitian yang didapatkan.

Kesimpulan dan saran disusun harus menjawab rumusan masalah.
Namun ketika dilontarkan pertanyaan mengenai kesulitan Widyaiswara dalam penyusunan artikel ilmiah hasil penelitian dan penyebabnya, ditemukan data yang bervariasi seperti tabel berikut:

Tabel 3. Data Hasil Wawancara II

\begin{tabular}{|c|c|c|}
\hline Penulis & Kesulitan Menyusun KTI & Penyebab Kesulitan \\
\hline 01.1 & $\begin{array}{l}\text { Mencari tema yang menarik untuk dibahas. } \\
\text { Kalau tema tidak menarik minat saya, saya } \\
\text { sulit mengembangkannya. }\end{array}$ & $\begin{array}{l}\text { Sulit mengembangkannya. } \\
\text { Bahannya juga sulit didapat. }\end{array}$ \\
\hline 01.2 & $\begin{array}{l}\text { Menentukan atau merumuskan masalah yang } \\
\text { tepat dan setelah itu menentukan metode } \\
\text { yang sesuai. }\end{array}$ & $\begin{array}{l}\text { Untuk penelitian yang menggunakan pendekatan } \\
\text { kuantitatif, karena dari sekian banyak identifikasi } \\
\text { masalah kita harus memilih yang sesuai itu didasarkan } \\
\text { pada teori-teori. } \\
\text { Tapi kalau untuk kualitatif, itu sulitnya menentukan } \\
\text { informan yang tepat, menyusun borang wawancara } \\
\text { yang tepat untuk menggali informasi dan setelah itu } \\
\text { merangkum atau menghighligt jawaban dari informan } \\
\text { dengan tepat. }\end{array}$ \\
\hline 01.3 & Kesulitan dalam masalah waktu. & $\begin{array}{l}\text { Karena banyak tugas dan kegiatan lain yang harus } \\
\text { dikerjakan. }\end{array}$ \\
\hline 01.4 & $\begin{array}{l}\text { Sebenarnya kalau diniatin bener tidak ada } \\
\text { yang sulit. }\end{array}$ & Tidak memberikan komentar. \\
\hline 01.5 & Malas dan tidak mau mencoba. & Karena tidak pernah mencoba. \\
\hline 01.6 & $\begin{array}{l}\text { 1. Membuat masalah apa yang mau diangkat. } \\
\text { 2. Bagaimana metodologi penelitiannya? } \\
\text { 3. Harus menggunakan metode apa? } \\
\text { 4. Bagaimana cara mengolah data yang } \\
\text { mudah. }\end{array}$ & $\begin{array}{l}\text { Karena tidak tahu harus diolah menggunakan apa. } \\
\text { Ide banyak tapi sampai pada pengolahan jadi bingung. }\end{array}$ \\
\hline 01.7 & $\begin{array}{l}\text { Mencari ide permasalahan yang ingin } \\
\text { diangkat. Ketika menulis, mengaitkan kalimat } \\
\text { atau paragraph yang satu dengan yang } \\
\text { lainnya. Referensi buku (nondigital) sangat } \\
\text { minim atau terbatas. }\end{array}$ & $\begin{array}{l}\text { 1. Butuh waktu yang serius dan tepat. } \\
\text { 2. Motivasi dari diri sendiri yang kadang naik turun. }\end{array}$ \\
\hline 02.5 & Dalam masalah waktu & Banyak kegiatan \\
\hline 02.6 & Tidak ada kesulitan & Tidak memberikan alasan \\
\hline 02.7 & Tidak ada kesulitan & Tidak memberikan alasan \\
\hline
\end{tabular}

Dari data tersebut dapat diuraikan bahwa beberapa Widyaiswara tidak mengalami kesulitan dalam penyusunan artikel ilmiah hasil penelitian berkenaan dengan sistematika penulisan. Namun pada sebagian dari mereka ada yang mengalami kendala misalnya kesulitan dalam mencari tema yang menarik untuk dibahas, menentukan rumusan masalah yang tepat, memilih metode penelitian, dan kesulitan dalam memilih referensi. 
Dan yang membingungkan adalah dalam hal menghubungkan antara paragraf yang satu dengan paragraf yang lainnya.

Sebagian yang lainnya mengalami kendala dalam hal waktu karena mereka memiliki tugas dan kegiatan lainnya yang harus dikerjakan sehingga sulit mengatur waktu dan mendapatkan kesempatan untuk menulis.

\section{Pembahasan}

Hasil penelitian menunjukkan bahwa semua naskah sudah mengikuti sistematika penulisan Karya Tulis Ilmiah dan menandakan bahwa diklat Karya Tulis Ilmiah bagi Widyaiswara sudah efektif untuk meningkatkan kompetensi Widyaiswara dalam menulis KTI. Hal ini dibuktikan dengan terjawabnya rumusan masalah penelitian ini, yaitu dalam perumusan permasalahan penelitian, perumusan kerangka teori, perumusan metode penelitian, penyusunan hasil dan pembahasan, dan penyusunan kesimpulan dan saran. Hal ini sejalan dengan pendapat Suhardjono (2015) bahwa sistematika penulisan KTI terdiri dari tiga bagian; bagian awal, bagian isi, dan bagian penunjang. Pada bagian isi terdiri dari pendahuluan, kajian teori/pustaka, metode penelitian, hasil dan pembahasan, serta simpulan dan saran. Pada bagian pendahuluan, unsur yang harus dipenuhi adalah kondisi ideal, permasalahan, penelitian terdahulu, dan alasan memilih topik permasalahan.

Selanjutnya, tujuan penelitian harus dinyatakan baik secara explisit maupun implisit. Hal ini sejalan dengan Perkalan No. 9 Tahun 2008 terdapat beberapa bagian pada pendahuluan yaitu;

Latar belakang, yang memuat motif yang mendorong penelitian/pengkajian, tingkat kebaruan topik yang diangkat, kespesifikan topik yang diteliti.

Identifikasi masalah, yang memuat: variabel penelitian/pengkajian, pola hubungan antar variabel, penggunaan notasi statistik matematika universal (jika bersifat kuantitatif), pertanyaan penelitian/pengkajian dan adanya asumsi.

Pada perumusan permasalahan penelitian, sebagian besar Widyaiswara sudah memahami apa yang harus diuraikan pada aspek tersebut seperti yang diungkapkan oleh Subagyo (2004) bahwa masalah yang akan dikemukakan dalam penelitian ini sebaiknya dirumuskan dalam bentuk kalimat pertanyaan yang singkat dan sederhana. Namun terdapat beberapa Widyaiswara yang mengungkapkan rumusannya tidak menggunakan kata "rumusan masalah" atau tidak dalam bentuk pertanyaan.

Selanjutnya, pada bagian kerangka teori, berdasarkan data dokumentasi terungkap bahwa sebagian naskah yang dianalisis kurang lengkap dan kurang sesuai dengan permasalahan yang diteliti. Meskipun tidak ada batas dan tidak perlu dibatasi berapa jumlah teori yang digunkana, namun seyogyanya sesuai dengan yang diungkapkan oleh ahli bahwa teori dalam penelitian kualitatif merupakan cantelan yang sangat penting bagi pelaksanaan penelitian. Teori dikembangkan berdasarkan variabel masalah yang diteliti. Hal ini sejalan dengan Perkalan No. 9 Tahun 2008 yang menyatakan bahwa pada bagian isi terdiri dari penyajian kerangka teoritik, metodologi, serta temuan dan pembahasan. Pada Kerangka Teoritik memuat:

1) Kajian kepustakaan.

2) Teori pendukung yang mutakhir dan relevan dengan obyek.

3) Definisi operasional variabel dan indikator yang digunakan.

4) Deskripsi kerangka berfikir.

Pada bagian metode penelitian ditemukan bahwa Karya Tulis Ilmiah Widyaiswara menggunakan metode penelitian yang bervariasi. Metode penelitian yang digunakan antara lain: metode penelitian content analysis, penelitian survei. pendekatan kualitatif dengan studi kasus, penelitian evaluation methods, dan metode-metode lain. Dengan kata lain, sebagian besar Widyaiswara sudah menguasai metode penelitian berdasarkan variabel masalah yang dipilih namun terdapat beberapa naskah yang tidak diungkapkan metode penelitiannya dan sebagian lagi kurang lengkap dan kurang rinci.

Dan pada temuan dan pembahasan memuat; pengungkapan permasalahan, pembahasan atas fakta atau peristiwa di lapangan, uraian dan analisis tinjauan/ulasan 
ilmiah, dan pembahasan/analisis atas fakta hasil penelitian/pengkajian dan dikaitkan dengan teori. Widyaiswara dalam penelitian sudah menggunakan cara-cara melakukan pengamatan dengan pemikiran yang tepat secara terpadu melalui tahapan-tahapan yang disusun secara ilmiah untuk mencari, menyusun serta menganalisis dan menyimpulkan data-data, sehingga dapat dipergunakan untuk menemukan, mengembangkan, dan menguji kebenaran dari suatu pengetahuan. Menurut Creswell (2013:4) bahwa proses penelitian kualitatif ini dimulai dari mengajukan pertanyaan dan prosedur, kemudian mengumpulkan data yang spesifik dari responden, menganalisis data secara induktif mulai dari tema-tema yang khusus ke tema-tema umum, dan terakhir menafsirkan makna data.

Pada bagian hasil penelitian dan pembahasan, semua Karya Tulis Ilmiah yang dianalisis sudah memaparkan hasil penelitian berdasarkan data yang telah dianalisis. Pada bagian pembahasan disajikan pembahasan berkenaan hasil penelitian. Hal ini sejalan dengan yang tercantum dalam peraturan penulisan KTI yang diberlakukan oleh Tim Jurnal Pusdiklat bahwa pembahasan dilakukan dengan menggunakan logika dan teori-teori yang ada dan pemisahan bagian-bagian dari pembahasan disesuaikan dengan temuan dan keperluan penelitian. Sejalan dengan apa yang dikatakan oleh Sobandi (2016) bahwa dalam analisis, pembahasan dan hasil penelitian, dapat dibagi dalam beberapa sub bagian sesuai dengan keperluan. Dan menurut Suhardjono (2015) bahwa hasil dan pembahasan merupakan hasil karya dari seluruh pikiran dan pengamatan tanpa didasarkan pada pendapat peneliti lain. Namun demikian, maka hasil dan pembahasan dalam penelitian ini merujuk kepada peraturan penulisan yang diberlakukan oleh Tim Jurnal Pusdiklat, yakni dalam pembahasan diuraikan berdasarkan hasil temuan kemudian diperkuat dengan teori-teori yang ada.

Demikian juga pada bagian penutup, semua naskah sudah memuat simpulan dan saran/rekomendasi. Simpulan merujuk kepada hasil penelitian sedangkan saran/rekomendasi merujuk kepada simpulan. Berkenaan dengan penulisan kesimpulan, dalam pedoman KTI Widyaiswara disebutkan bahwa dalam bagian penutup memuat; 1) kesimpulan (bukan ringkasan) dari berbagai gejala yang telah diamati, 2) saran/Rekomendasi, berisi berbagai alternatif pemecahan masalah yang bersifat sangat spesifik dan jelas untuk direkomendasikan.

Sementara menurut Sobandi (2016) kesimpulan dan rekomendasi berisi kesimpulan dari penelitian yang dilakukan, dengan mengungkapkan kelebihan dan kekurangan dari metode yang digunakan ataupun saran kebijakan kepada pihak-pihak yang terkait dengan substansi penelitian tersebut Selain itu, diungkapkan pula rekomendasi yang berisi kemungkinan penelitian lebih lanjut, dan tindakan yang harus dilakukan oleh pihakpihak yang terkait dengan substansi penelitian. Sedangkan menurut Suhardjono (2015) kesimpulan memenuhi ciri-ciri sebagai berikut; 1) ingkat, jelas, dan padat, merupakan intisari dari suatu analisis/pembahasan dari suatu masalah, 2) harus konsisten antar antara pembahasan dan kesimpulan, 3) harus disusun berdasarkan rumusan masalah dan tujuan penelitian.

Sedangkan saran yang perlu diperhatikan yaitu; 1) saran harus berpijak pada kesimpulan hasil penelitian yang dilakukan dan 2) arah dari saran harus jelas dan operasional atau bersifat konkrit dan dapat dilaksanakan.

Singkatnya, KTI Widyaiswara walaupun dibeberapa aspek masih belum tajam namun terdapat sedikit benang merah antara pemahaman Widyaiswara terkait permasalahan dalam penelitian ini dengan naskah artikel Widyaiswara yang sudah dipublish dan naskah pada umumnya sudah sesuai dengan ketentuan penyusunan Karya Tulis Ilmiah menurut para ahli (teori) dan ketentuan yang ditetapkan oleh perkaLAN No. 9 tahun 2008. Dengan kata lain, Diklat KTI bagi Widyaiswara efektif dalam meningkatkan kompetensi Widyaiswara dalam menyusun $\mathrm{KTI}$. 


\section{PENUTUP}

\section{Simpulan}

Berdasarkan temuan dan pembahasan dapat disimpulkan bahwa kemampuan Widyaiswara dalam menyusun KTI khususnya dalam perumusan permasalahan penelitian, perumusan kerangka teori, perumusan metode penelitian, penyusunan hasil dan pembahasan, dan penyusunan kesimpulan dan saran meningkat setelah mengikuti diklat KTI Widyaiswara. Dengan kata lain, Diklat KTI bagi Widyaiswara efektif dalam meningkatkan kompetensi Widyaiswara dalam menyusun KTI.

\section{Rekomendasi}

Berdasarkan simpulan tersebut, peneliti menyampaikan rekomendasi sebagai berikut:

1) Pusdiklat tetap memprogramkan diklat KTI bagi Widyaiswara.

2) Dalam penelitian ini masih terdapat kekurangan yaitu dalam hal melakukan wawancara dengan responden kurang mendalam, pertanyaan masih bersifat umum dan terbuka, serta responden kurang siap dalam menjawab pertanyaan sehingga data yang terkumpul menjadi kurang lengkap.

3) Perlu diperdalam pemahaman Widyaiswara dalam tiga hal mencari ide permasalahan atau tema yang menarik untuk dibahas, perumusan kerangka teori, dan bagaimana perumusan metode penelitiannya.

4) Terdapat kekurangan pemahaman Widyaiswara akan kajian teori, maka dari itu perlu diteliti lebih dalam lagi mengenai kajian teori. 


\section{DAFTAR PUSTAKA}

Bangun, W. (2008). Intisari Manajemen. Jakarta: Prenada Media Grup.

Creswell, J. W. (2013). Research Design Pendekatan Kualitatif, Kuantitatif dan Mixed. Yogyakarta: Pustaka Pelajar.

Hermansyah, \& Tamim. (2002). Diklat sebagai Suatu Sistem. Jakarta: LAN RI.

Makmur. (2011). Efetivitas Kebijakan Kelembagaan Pengawasan. Bandung: Refika Aditama.

Peraturan Kepala Lembaga Administrasi Negara Nomor 9 Tahun 2008 tentang Pedoman Penyusunan Karya Tulis bagi Widyaiswara. (2008).

Peraturan Menteri Pendayagunaan Aparatur Negara dan Reformasi Birokrasi No. 22 Tahun 2014 tentang Jabatan Fungsional Widyaiswara dan Angka Kreditnya. (2014).

Peraturan Pemerintah Nomor 101 Tahun 2000 tentang Pendidikan dan Pelatihan Jabatan Pegawai Negeri Sipil. (2000).

Saddhono , K., \& Slamet, S. Y. (2012). Meningkatkan Keterampilan Berbahasa Indonesia. (Cetakan ke-1). Bandung: Karya Putra Darwati.

Sembiring, M. (2012). Budaya dan Kinerja Organisasi. Cetakan Pertama. Bandung: Fokusmedia.

Simamora, H. (2006). Manajemen Sumber Daya Manusia. Yogyakarta: STIE YKPN.

Sobandi, B. (2016). Metode Penelitian II. Jakarta: LAN RI.

Subagyo, P. J. (2004). Metode Penelitian Dalam Teori dan Praktek. Jakarta: PT. Rineka Cipta.

Sugiono. (2009). Metode Penelitian Pendidikan, Pendekatan Kuantitatif, Kualitatif, dan R\&D. Bandung: Alvabeta.

Suhardjono, S. (2015). Strategi Menyusun Penelitian Tindakan Kelas. Jakarta: ANDY.

Suparno, \& Yunus, M. (2008). Keterampilan Dasar Menulis. (Cetakan ke-18). Jakarta: Universitas Terbuka. 